\title{
聴力保存し得た頸静脈球型頸静脈球腫瘍例
}

\author{
栗山 博道 - 細田 泰男 $\cdot$ 辻 裕之 \\ 小田 恭弘*・友田 幸一・山下 敏夫

\section{Preservation of Hearing in a Case of Glomus Jugulare Tumor} \\ Hiromichi Kuriyama, Yasuo Hosoda, Hiroyuki Tsuji, \\ Yasuhiro Shouda, Koichi Tomoda and Toshio Yamashita \\ (Kansai Medical University)
}

\begin{abstract}
A 60-year-old female had experienced facial palsy for 6 months and pulsation tinnitus for 9 months in the left ear without hearing loss. Physical examination revealed a vascular mass in the left hypotympanum and no cranial nerve deficits, except in the facial nerve (facial palsy score 27/40). MRI revealed a glomus jugulare tumor along the internal carotid artery. This tumor was classified as class $\mathrm{C} 2$ according to Fisch's classification.

An Infratemporal fossa approach was used, with preservation of middle ear structure and reconstruction of the external auditory canal. The tumor was extirpated with preservation of the cochlea, vestibule and facial nerve. After removal of the tumor, the external auditory canal was reconstructed using bone paté and the ossicular chain was reconstructed using a ceramic prosthesis.

Two years postoperatively, the patient has neither hearing problems nor tinnitus, and only mild facial palsy.
\end{abstract}

Key words : hearing preservation, glomus jugulare tumor, canal reconstruction

\section{はじめに}

頸静脈球腫瘍は，有色人種に少なく本邦ではまれな疾 患で手術報告例も少ない. 特に頸静脈球型頸静脈球腫陽 は, 解剖学的に複雑な位置に存在し, 内頸動静脈, 下位 脳神経などが周辺に存在することから，外科的治療には 十分な解剖学的知識が必要となる.

今回著者らは, 中耳, 内耳構造を温存して, 外耳道括 よび下鼓室を大きく削除し広い術野で腫瘍を除去した後， これらを再建することで顔面神経および聴力を保存し得 る術式を試みたので報告する。

\section{症 例}

患者は60歳女性, 1993年 7 月頃より左拍動性耳鳴を認
め，同年10月より左顔面神経麻痺が出現した．1994年 2 月近医耳鼻科を受診し，左下鼓室に拍動性腫瘤を指摘さ れ当科を受診した。

1) 初診時所見

聴力は正常, 左顔面神経麻痺スコアーは $27 / 40$ 点で, 耳鏡所見は左鼓膜後下象限に赤褐色の拍動性腫瘤が透見 された．全身所見特に異常認めず，血圧は $120 \sim 140 / 70$ $\sim 80 \mathrm{mmHg}$ と正常であった.

2 ) 画像所見

MRI では造影 T1 強調画像にて, 頸静脈孔より上内 方に約 $2 \mathrm{~cm}$ の辺縁不整な腫瘍が認められた.内頸動脈 垂直部の後面に接している頸静脈球型頸静脈球腫瘍が凝 われ，Fisch ${ }^{1)}$ の分類による class C2 に相当すると考兄 
られた(図 1 ).

脳血管造影では腫瘍部に左上行咽頭動脈, 後耳介動脈, 後頭動脈よりの血液の流入を認めた(図 2 ).

以上の結果より頸静脈球型頸静脈球腫瘍と診断し外科 的加療を行らこととした。

\section{術式}

1) 術前塞栓術

術 3 日前に左上行咽頭動脈, 後頭動脈に対してPVA (polyvinylalcohol) particle にて塞栓術を施行した. 本症 例において塞检術中選択的静脈採血を行ったところ頸静 脈のカテュラミン值はノルアドレナリンが塞栓前 18826 $\mathrm{pg} / \mathrm{ml}$, 塞栓後 $693 \mathrm{pg} / \mathrm{ml}$, ドーパミンが塞栓前 3791 $\mathrm{pg} / \mathrm{ml}$, 塞栓後 $127 \mathrm{pg} / \mathrm{ml}$ にそれぞれ減少し，また塞栓 前に血圧 $170 / 120 \mathrm{mmHg}$ であったものが塞栓後に $110 /$ $60 \mathrm{mmHg}$ 前後に低下した。

2) 手術

皮切はY字切開とした. 最初に胸鎖乳突筋を乳様突起 付着部より離切し顎二腹筋とともに下前方に翻転した. 次に迷走神経, 舌下神経, 顔面神経本幹を観察し, さら に内頸静脈を頸静脈孔付近をで露出した。乳突削開術と ともに左外耳道壁は 12 時から 9 時の位置までの約 $2 / 3$ を 削除し, さらに下鼓室骨も削除した。但し, 外耳道皮膚 および鼓膜には，一切切開を加光ず温存した。アブミー
キヌタ関節を離断しキヌタ骨を除去したのち，顔面神経 を第 2 膝部より耳下腺内本幹まで露出した。腫瘍は顔面 神経垂直部で一部癒着を認めたが，慎重に剥離した後， 顔面神経を前外方へ移動した. この時点で頸静脈球を中 心に和き，錐体骨下方に浸潤した腫瘍が明視下に置かれ たが(図 $3 \mathrm{a}$ ), 本腫瘍は易出血性であるとともに, 周囲 に強く癒着し剥離は容易ではなかった。出血を制御する ため, S 状静脈洞特よびその前後の後頭蓋窩硬膜を露出 し, S 状静脈洞, 頸静脈球, 頸静脈本幹を一連として明 視下に执いた。この上で $\mathrm{S}$ 状静脈执よび内頸静脈を結紮 し, さらに頸静脈球内に侵入し, 下錐体静脈洞よりの出 血をオキシセル綿で塞栓した. 上記の止血操作を終了し た後, 腫瘍摘出を開始したが，頸静脈球に浸潤した腫瘍 に対して頸静脈球壁の内側壁のみを残してその他は腫瘍 と共に切除した．前方では頸動脈管の後壁と癒着を認め たが，慎重に剥離し内耳を保存してほぼ全摘が可能であ った。

腫瘍を摘出した後に人工耳小骨にて伝音系を再建(図 $3 \mathrm{~b})$ 乙, 大きく削除された下鼓室执よび外耳道後下壁 を骨片とbone paté で再建し，温存した外耳道皮膚执よ び鼓膜を元に戻した．最後に下方に翻転した胸鎖乳突筋

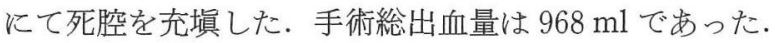
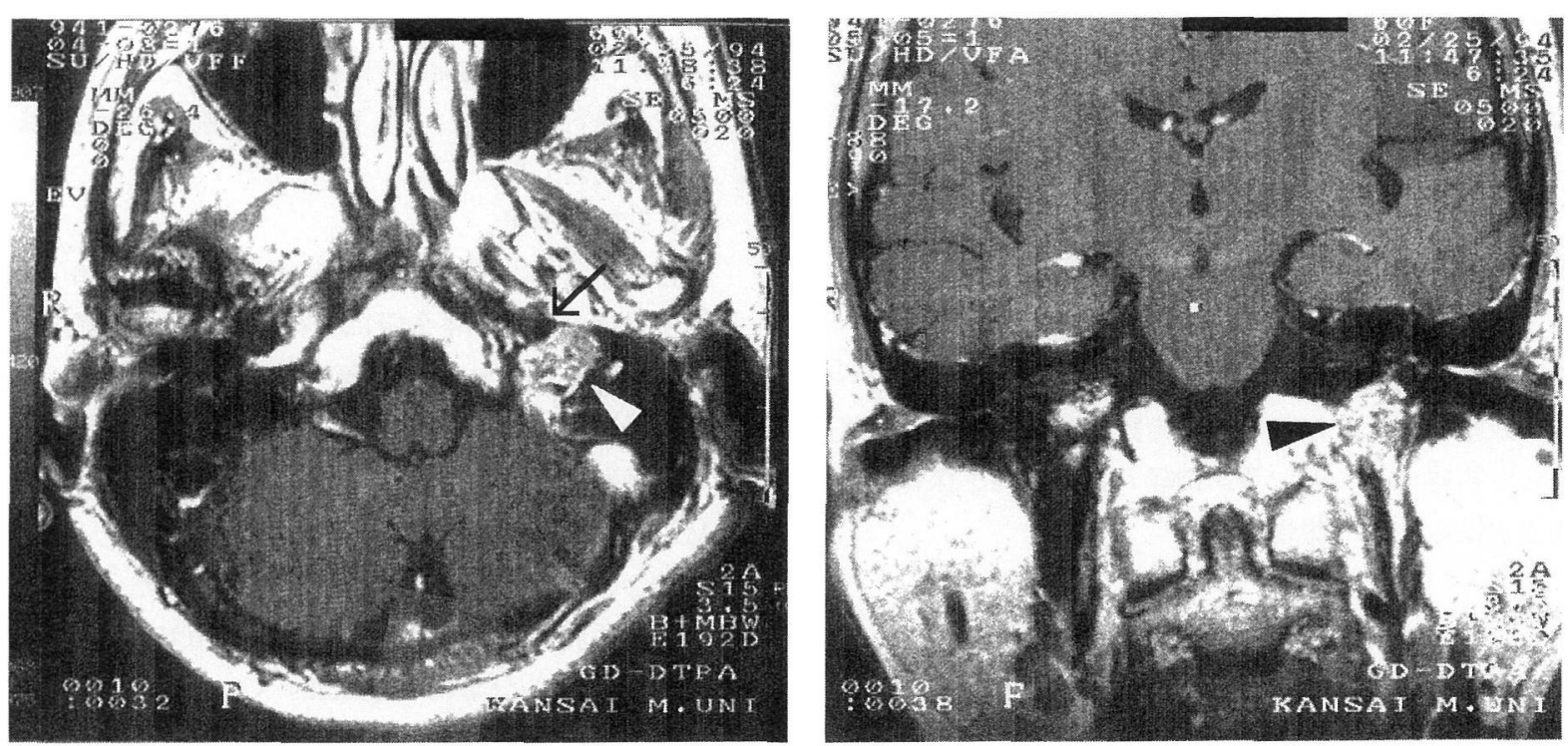

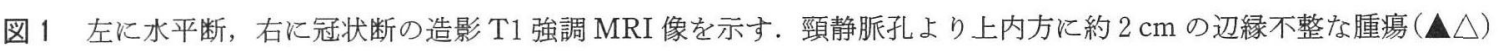
が造影され，内頸動脈垂直部( $\uparrow$ )の後面に接している. 


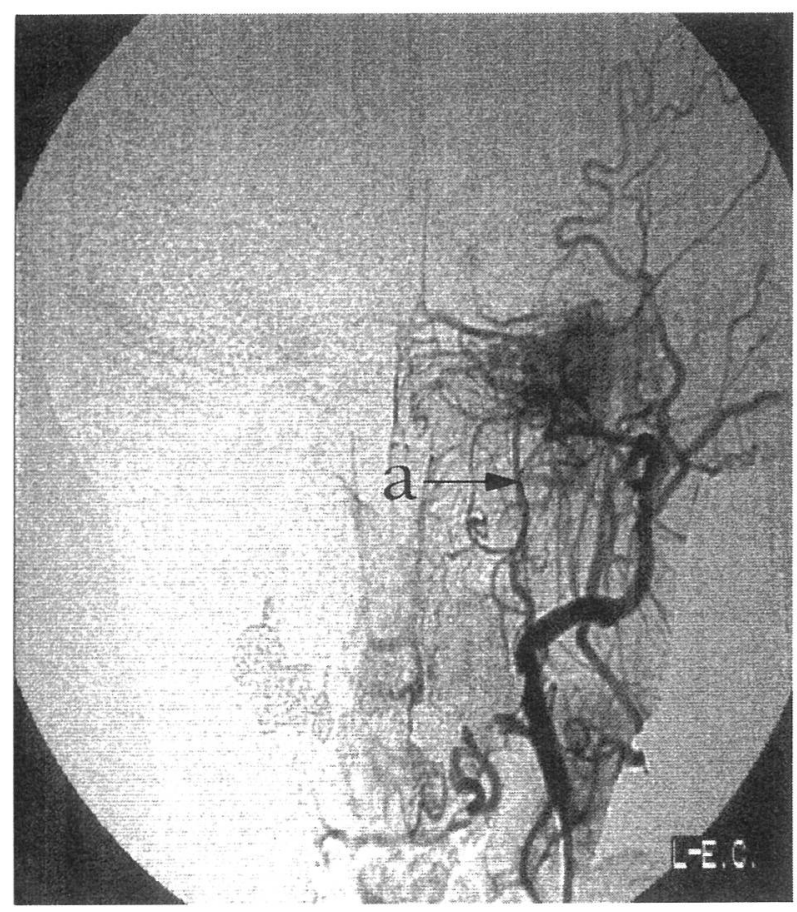

正面像

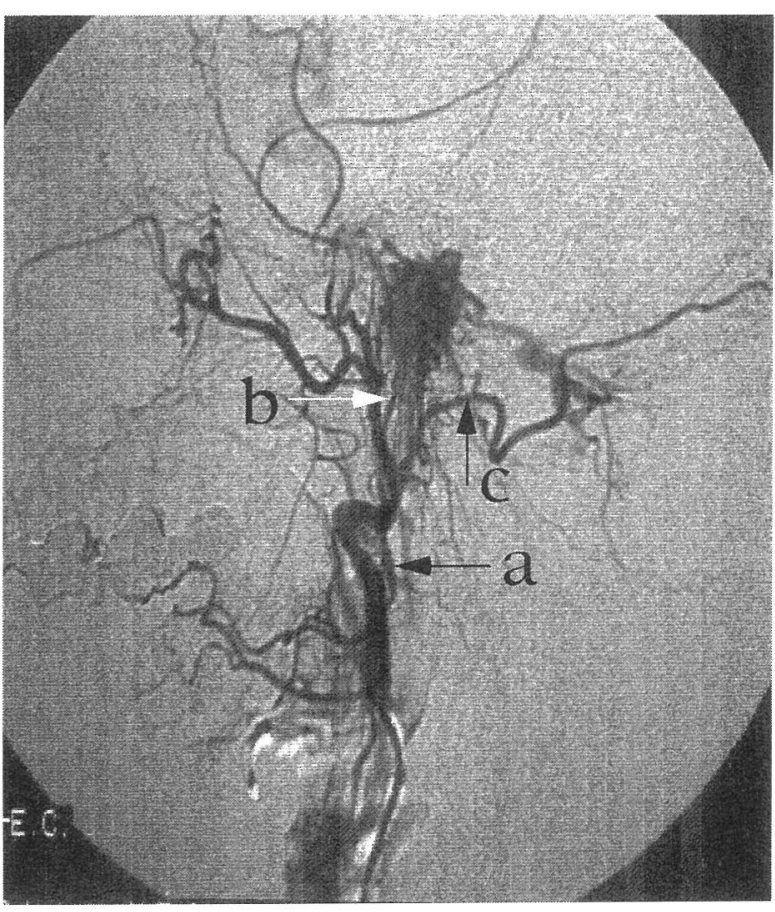

側面像

図 2 脳血管造影では腫瘍に左上行咽頭動脈 ( a ), 後耳介動脈 ( b ), 後頭動脈 ( c ) より多量の血液の流入を認めた.

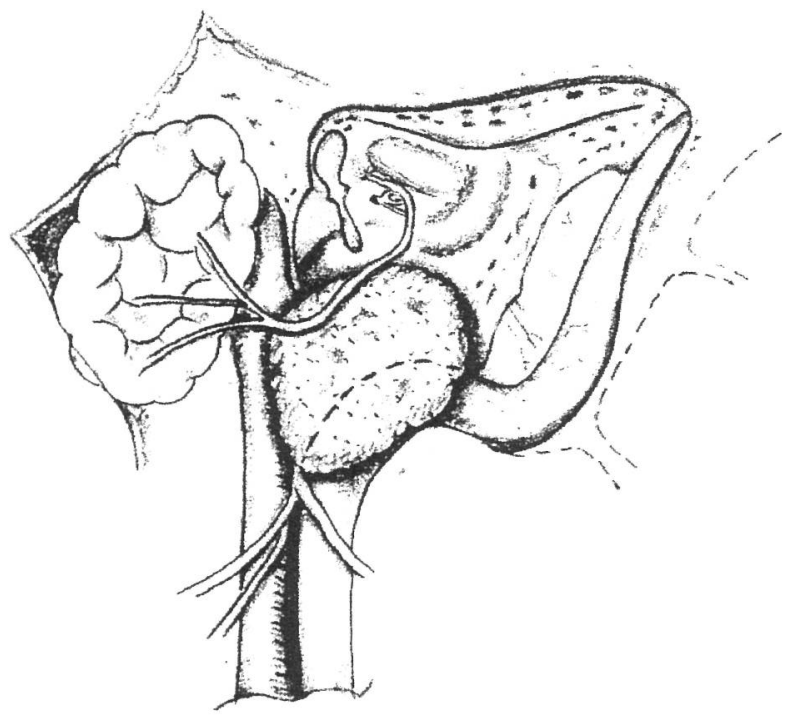

(a)

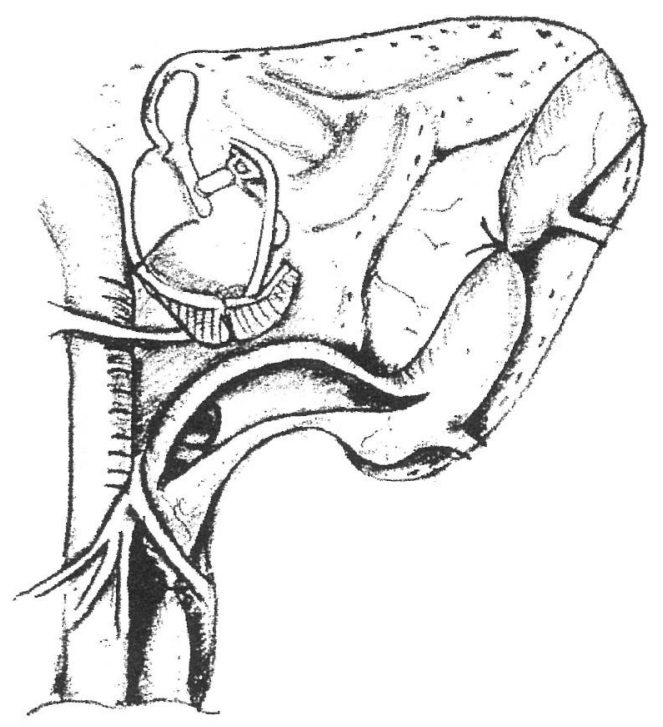

(b)

図 3 外耳道皮膚扎よび鼓膜を温存し, 外耳道骨は 12 時から 9 時の位置までの約 $2 / 3$ を削除し, さらに下鼓室 骨も削除した。この時点で頸静脈球を中心に腫瘍が明視下に置かれた( a ). 総頸静脈, S 状静脈洞を結 禁し腫瘍を摘出した後に人工耳小骨にて伝音系を再建した(b). 

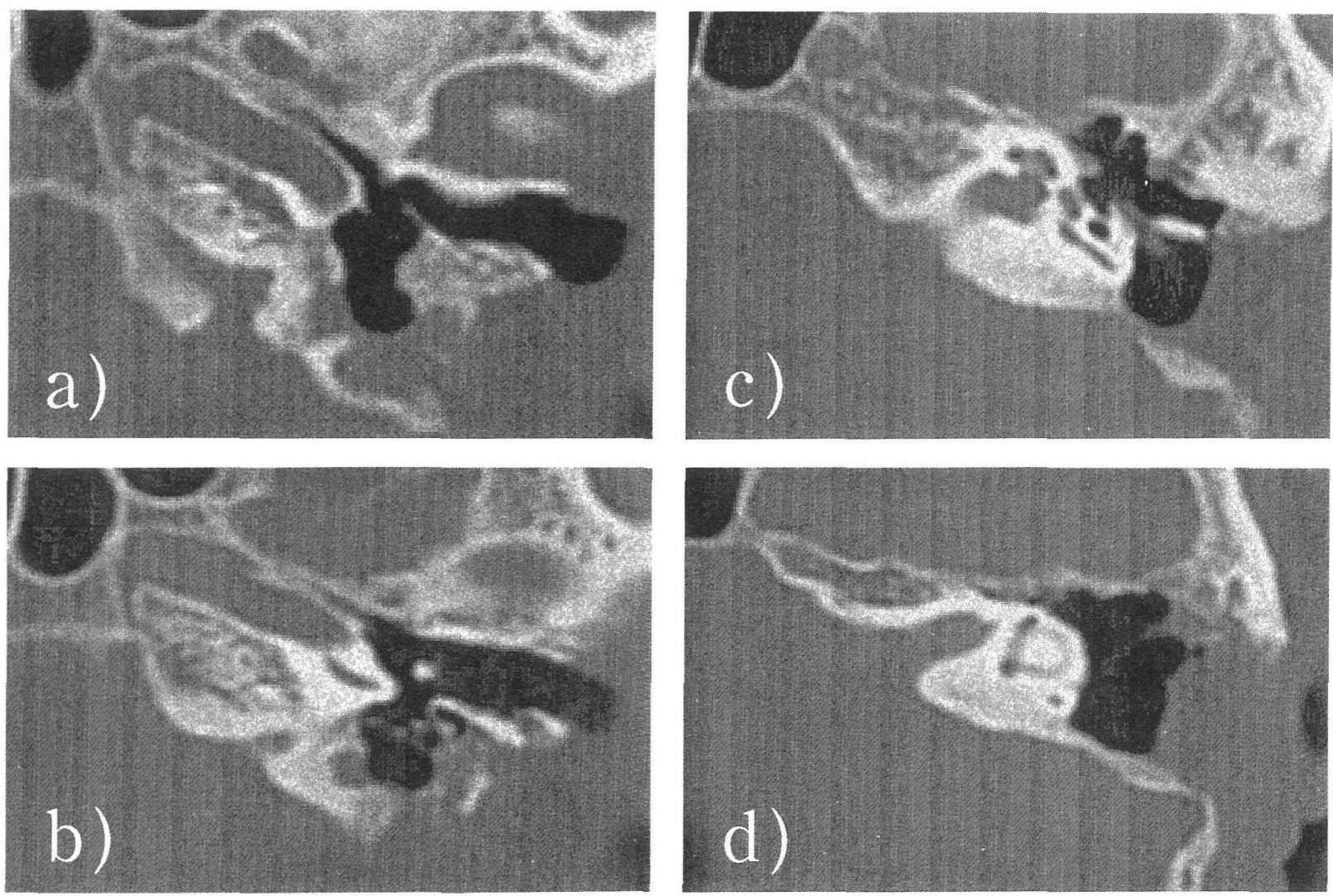

図 4 術後 6 カ月の CT を示す.頸動脈管後面まで骨削開されて拈り，また再建外耳道括よび下鼓室骨は骨化している(a). 伝音再建に用いた人工耳小骨 $(\mathrm{b})$, 蝸牛 (c), 半規管 (d)が確認される.

\section{術後結果}

術後経過に異常なく，與下，発声機能共に良好で，ま た䯣膜炎等の頭蓋内合併の症状を認めなかった。

術後 6 カ月の CT を図 4 亿示す.（a）では頸動脈管後 面まで骨削開されているのが分かり，また再建外耳道掠 よび下鼓室骨が充分飞骨化しているのが観察できる. (b ) では伝音再建に用いた人工耳小骨が所定の位置に認めら れる、（c）では蝸牛，(d)では半規管が温存されている のが確認された。現在術後 2 年であるが聴力は約 30 $\mathrm{dB}$ 水平型と実用聴力を保っている(図 5 ).

\section{考察}

1941年 Guild2) が頸動脈小体と類似した組織が頸静脈 球の壁，鼓室に存在することを明らかにし，これを Glomus jugulare と命名した. 1945年 Rosenwasser ${ }^{3}$ が Glomus jugulare より発生した頸静脈球腫瘍を初めて報 告している. 本邦では1956年切替ら ${ }^{4)}$ が最初の報告を行

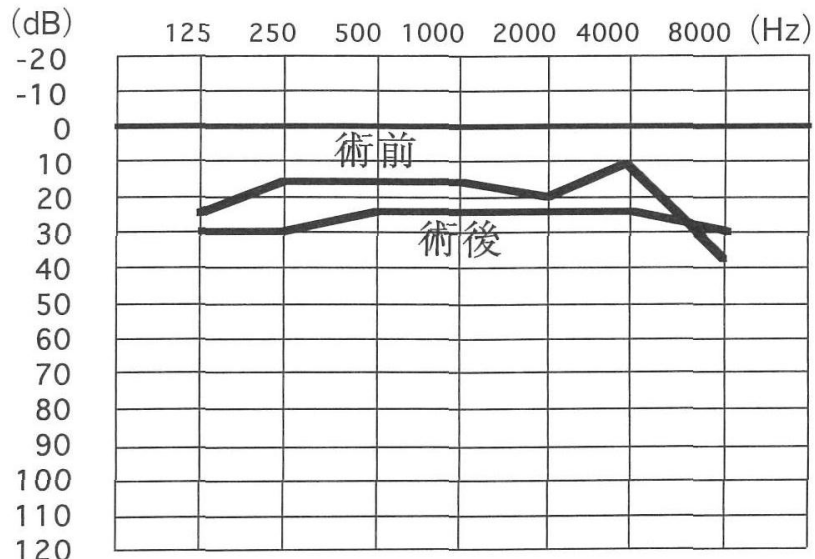

図 5 術前拉よび術後 2 年聴力像

っている. 本腫瘍はとの発生部位により鼓室型と頸静脈 球型とに分類されている5)。頸静脈球型頸静脈球腫瘍は, 
解剖学的に複雑な位置に存在し，内頸動静脈，下位脳神 経などが周辺に存在し，しかも血流に富む腫瘍であるこ とから外科的に全摘出するには困難を伴らことが多い． そこで著者らは，術 3 日前に血管造影を行い，その栄養 血管であった左上行咽頭動脈, 後頭動脈, 後耳介動脈の 5ち上行咽頭動脈, 後頭動脈に対してPVA particle に て塞栓術を施行した. この操作により, 術中の出血量を 約 $1000 \mathrm{ml}$ に抑えることができ，本腫瘍には必須の前処 置と考兄られた6) 9)。 また頸静脈球腫瘍は一部にカテュ ラミンを分泌する functioning paragangliomaがあり, 塞栓術や摘出術により hypertensive/hypotensive crisis を引き起こす可能性があると報告されている10111，本症 例において塞栓術時，カテュラミン値は劇的な低下を示 し血圧も急激に低下したが，ドブタミンの少量点滴で問 題なく経過した。

頸静脈球腫瘍の術式として有名な Fisch ${ }^{1)}$ の infratemporal fossa approach があり，これは type A，B，Cに分 類されている. type A は内頸動脈を頸動脈管入口部か ら垂直部まで開放するもので， type B は水平部まで， さらに type $\mathrm{C}$ は海綿静脈洞部まで開放するものである. 著者らの用いた方法は type A 飞相当するが，この方法 によれば骨性外耳道は削除，外耳道軟部組織は閉鎖する ため中耳伝音系は儀牲となり聴力は失われる。これに対 して, Jackson ${ }^{6)}$ は骨性外耳道, 中耳腔をともに温存し, 聴力を保存する basic transtemporal skull base approach を報告している。しかし，これは骨性外耳道を温 存する方法で, 頸静脈球に限局した腫瘍にのみ適用可能 であり, 本症例のように内頸動脈にまで達した class C に属する腫瘍では術野が狭く限界がある，とこで著者ら は骨性外耳道掞よび下鼓室を削除し， infratemporal fossa approach type A と同等な術野を確保した上で腫 瘍を切除し, 最後に中耳, 外耳を再建することで聴力の 温存に成功した. 従って, 本術式は infratemporal fossa approach type A with external canal reconstruction と呼 べる. この外耳道の再建については，骨性外耳道は12時 から 9 時までの約 $2 / 3$ が削除され，さらに鼓室骨の一部 も削除し，これらの骨性の枠組みを bone paté 拉よび皮 質骨にて再建した。この再建を成功させるのに重要なの は嗢膜を含めた軟性外耳道の温存と考元ている. 外耳道 皮膚は術後の感染予防に役立ち, さらに再建外耳道の重 要な血行路となることから，著者らはこれに全く切開を 加えず温存することに留意している，また，このよらに
解剖学的に複雑な形態を示す鼓室骨の再建にも, bone paté は自由な形状を保つことができ非常に有効と考光 られ, 術後 2 年の現在も外耳道の形態に異常を認めてい ない，以上のごとく， Fisch ${ }^{1)}$ の原法によれば外耳中耳 の枠組みを保てないために卮音系は犠牲となったが，著 者らの方法を用いれば infratemporal fossa approach の 術野を確保しながら伀音系も温存することが可能と考兄 られた。

次に顔面神経の処理方法について考案する. Woods ら ${ }^{12)}$ の60例の報告によると顔面神経の処理法としては 减荷, 神経移動, 神経縫合, 神経移植, 神経吻合, の 5 種類をあげて扣り，最も多かったのは神経移動術であっ たとしている. 本症例は術前顔面神経麻疩スコアーは 27 点であり, 顔面神経に腫瘍は強く癒着していた。 この時 点で神経移動を行うべきか，あるいは一塊切除の後に神 経移植を行らか迷ったが，良性腫瘍であったことまた中 程度の麻痺であったことから顔面神経に腫瘍が一部付着 した状態で移動保存した。術後退院時に，スコアーは15 点となったが，その後 2 年の現在ではそれ以上の悪化傾 向はなく不変であり,さらに長期的に再発ならびに顔面 神経麻痺スコアーについて観察する必要があると考兄ら れる。

その他顔面神経以外の下位脳神経の損傷の危険性もあ ったが，これに対して頸静脈球の外側壁を腫瘍とともに 切除し内側壁を温存することで, これら下位脳神経は保 存され, 術後の燕下, 発声機能に異常を認めなかった。 また, 本手術操作は S 状静脈洞結禁以外はすべて硬膜外 の操作であり, 術後の髄夜漏あるいは髄膜炎等も認めら れなかった。

以上述べた如く, 頸静脈球腫瘍は良性腫瘍であり, 可 能な限り機能保存を考えるべきと思われるが，臨床的に は悪性の経過をとる例が報告されて拉り，安易な摘出術 等は極力さけるべきと考兄られる13)。また，放射線療 法14) 16)を施行する報告も見られるが，根治性がなく 2 次性癌の可能性を考学れば，機能を保存した全摘が理 想的と思われる．この意味でも今回の術式は有用な方法 と考えられた.

\section{まとめ}

1 ）聴力を温存し摘出可能であった class C2 頸静脈 球型頸静脈球腫瘍の 1 例を報告した。

2 ）塞栓術の併用により，出血はコントロールされ, 
本手技は術前に必須と考兄られた。

3 ) infratemporal fossa approach type A と同等の広

い術野を確保しつつ, 軟性外耳道を温存し骨性外耳道,

下鼓室および中耳伝音系を再建することで実用聴力の温 存が可能であった.

\section{参考文献}

1) Fisch U : Infratemporal fossa approach for glomus tumors of the temporal bone. Ann Oto Rhino Laryngol 91 : 474 479, 1982.

2) Guild SR : A hitherto unrecognized structure, the glomus juglaris, in man. Anat Rec 79 Suppl $1: 28,1941$.

3 ) Rosenwasser H : Carotid body tumor of the middle ear and mastoid. Arch Otolaryngol $41: 64 \sim 67,1945$.

4 ）切替一郎, 鳥山寧二 : 側頭骨の大部を侵した中耳傍神経筋 腫の一例とその文献的考察. 日耳鼻 $59: 1435 \sim 1441,1956$.

5 ) 切替一郎, 佐藤佰正, 沢木修二 : 中耳傍神経筋腫の一例. 日耳鼻 $63: 2231 \sim 2239,1960$.

6 ) Jackson CG : Diagnosis for treatment planning and treatment options. Laryngoscope $103: 17 \sim 22,1993$.

7 ) Young NM, Wiet RJ, Russell EJ, et al : Superselective embolization of glomus jugulare tumors. Ann Otol Rhinol Laryngol $97:$ :613 620, 1988.

8 ) Simpson GT II, Konrad HR, Takahashi M, et al : Immediate postembolization excision of glomus tumors. Arch Otolaryngol $105: 639 \sim 643,1979$.
9) Murphy TP and Brackmann DE : Effect of preoperative embolization on glomus jugulare tumors. Laryngoscope $99:$ 1244 1247, 1989.

10) Farrior JB : Cartinoid apudoma arising in a glomus jugulare tumor; review of endocrine activity in glomus jugulare tumor. Laryngoscope $90: 110 \sim 119,1980$.

11) Schwaber MK, Glasscock ME, Jackson CG, et al : Diagnosis and management of catecholamine secreting glomus tumors. Laryngoscope $94: 1008 \sim 1015,1984$.

12) Woods CI, Stranick B and Jackson CG : Surgery from glomus tumors; the otology experience. Laryngoscope $103: 65 \sim 70,1993$.

13）渡辺健一朗, 森山 寛, 佐野真一, 他 : Glomus jugulare tumor の治療経験. 耳展 $28: 607 \sim 616,1985$.

14) Cole MJ and Beiler D : Long-term results of treatment for glomus jugulare and glomus vagale tumors with radiotherapy. Laryngoscope $104: 1461 \sim 1465,1994$.

15）白馬 明：頭蓋底部に広汎な進展をきたした glomus tumor の 1 例. 脳神経外科 $2: 403 \sim 408,1974$.

16) Hudgins $P T:$ Radiotherapy for extensive glomus jugulare tumors. Radiology $103: 427 \sim 429,1972$.

$$
\left(\begin{array}{l}
\text { 原稿受付 : 平成 } 8 \text { 年 } 12 \text { 月 } 5 \text { 日 } \\
\text { 原稿採択 : 平成 } 9 \text { 年 } 3 \text { 月 } 12 \text { 日 } \\
\text { 別刷請求先 : 栗山博道 } \\
\text { 干 } 570 \text { 守口市文園町 } 10-15 \\
\text { 関西医科大学耳鼻咽喉科学教室 }
\end{array}\right)
$$

